\title{
The Frequency of Use of Legislative and Non-Legislative Tools in Five Countries
}

\author{
Osnat Akirav \\ Correspondence: Western Galilee College, The head of the department of political science, Israel. E-mail: \\ osnatak@bezeqint.net
}

Received: May 23, 2021 Accepted: June 20, $2021 \quad$ Online Published: July 12, 2021

doi:10.5539/res.v13n3p14 URL: https://doi.org/10.5539/res.v13n3p14

\begin{abstract}
This study analyzes the use of legislative and non-legislative tools, which has rarely been done simultaneously. I collected data about the frequency of use of legislative tools (presenting and passing legislation) and non-legislative tools (making one-minute speeches, written and oral parliamentary questions and motions for the agenda) in five countries: the US, the UK, Canada, Australia and Israel. The results confirm my three hypotheses. Legislators from Australia, the UK and Canada use fewer legislative tools because their use is more constrained than in the US and Israel. Legislators use more semi or unconstrained tools that involve publicity than those that simply appear on the record. Finally, opposition members use more non-legislative tools while government members use more legislative tools. However, the degree of constraint on the use of the tool moderates this finding. The study provides a comprehensive understanding of the legislators' strategic use of legislative and non-legislative tools.
\end{abstract}

Keywords: legislative tools, non-legislative tools, opposition members, cost-benefit analysis

\section{Introduction}

Legislative behavior has received a great deal of research attention whether it looked at one country (Koger 2003; Tuttnauer 2020) or compared several countries (Bäck and Debus 2016; Jenkins and Monroe 2016; Wegmann 2020). The research has focused on the determinants of introducing and voting on legal proposals, on the length of time such proposals are in the legislative process and on voting behavior using roll calls. In addition, the literature analyzes agenda setting, productivity and effectiveness using the legislative process (Bowler 2010; Döring 2017; Sulkin et al. 2015). Other studies have investigated the use of non-legislative tools such as parliamentary questions (by country and comparatively) (Kellermann 2016; Otjes and Louwerse 2018; Saalfeld and Bischof 2013; Zittel et al. 2019) and one-minute speeches and early day motions but only in a single country (one-minute speeches in the US, early day motions in the UK and motions for the agenda in Israel) (Akirav 2021; Kellermann 2013; Pearson and Dancey 2011). In recent years there has been a new focus on legislative speech making (Bäck and Debus 2016; Proksch and Slapin 2015). However, the investigation of both legislative and non-legislative tools together has been neglected. This study will fill the gap in the comparative literature on legislators' behavior by analyzing the use of both legislative and non-legislative tools simultaneously (Akirav 2014; Proksch and Slapin 2015; Sorace 2018).

The current study analyzes the frequency of use of legislative and non-legislative tools in five countries: the US, the UK, Canada, Australia and Israel. There are several explanations for this choice. First, Israel, Canada and Australia have all four legislative and non-legislative tools: legislation, parliamentary questions, one-minute speeches and motions. The UK has three of them (legislation, parliamentary questions and motions). The US has legislation and one-minute speeches. Therefore, we can compare two of the most neglected non-legislative tools: one-minute speeches and motions. Furthermore, as demonstrated previously, in all four countries the procedures governing one-minute speeches are similar and it is considered an easy, unconstrained parliamentary tool to use. Hence, the comparison between the four countries based just on one-minute speeches can provide useful insights.

Second, as previous studies noted, electoral systems have several critical implications for the political lives of legislators (Dassonneville et al. 2017; Heitshusen et al. 2005; Strøm 1997). Hence, I considered the similarities and differences in the electoral systems of the five countries. Australia, Canada and the UK are relatively similar in their social, cultural and political characteristics. All are well-established representative democracies with a bi-cameral legislature dominated by two major and at least one minor party. All three countries use single member constituencies and an electoral system based on variants of the Westminster model (Heitshusen et al. 2005). However, there are differences. Canada and the UK have first-past-the-post systems, while Australia uses the single member district 
majority-preferential or alternative vote system. Nevertheless, in practice these electoral systems function in relatively similar ways (Heitshusen et al. 2005; Shugart and Taagepera 2017). In all three countries the major decisions about candidate selection are made largely at the constituency level. Supervision by national party agencies takes place in the UK and by state party agencies in Australia. In Canada, supervision is unusual, although the national party leader does have a rarely exercised veto over constituency selections. The US House of Representatives also uses the first-past-the-post method, but the role of the party is less dominant than in the UK, Australia, Canada and Israel (Dassonneville et al. 2017; Heitshusen et al. 2005; Terjesen and Trombetta 2017). At the opposite end of the spectrum from the first-past-the-post method is Israel, which uses a closed-list proportional representation system with one constituency (Terjesen and Trombetta 2017).

This study contributes to the literature in several ways. First, an analysis of legislative and non-legislative tools together improves our understanding of the strategies involved in legislators' behavior. Second, the study identifies two criteria that determine how parliamentary tools are used: the degree to which the use of the tool is constrained and its visibility, meaning whether it involves publicity or is simply a matter of record. Third, the study compares three parliamentary terms in five different countries to investigate the changes in the use of the various tools over time and between the countries. The countries differ in their electoral systems and the dominance of political parties, which can help us understand the incentive of legislators from each country to use legislative and non-legislative tools simultaneously. Finally, I assess the simultaneous use of legislative and non-legislative tools by those in government and those in the opposition.

The article proceeds as follows. The first section surveys the literature on the legislative and non-legislative tools. Next follows an analysis of the procedures of legislative and non-legislative tools, which leads to their division into three categories based on the degree of constraint involved in their use and two categories related to the degree of publicity involved in their use. The third section discusses how those in government and those in the opposition use legislative and non-legislative tools. The fourth section describes the data and methodology employed in the article. The results of the main analyses are detailed in the fifth section with a discussion of the findings. The final section presents the conclusions of the article.

\section{Literature Review}

\subsection{Legislative and Non-Legislative Tools}

Legislative activities are activities with direct material consequences for society, as they lead directly to the passage of new legislation or legislative reform. Non-legislative activities are activities with no direct material consequences for society, because no law is changed (Green-Pedersen 2010). However, as Green-Pedersen (2010) argued, when many more private bills are presented than laws are passed, the presentation stage of a bill could be considered a non-legislative activity. There are countries in which legislators can present many private bills, but the next steps are much more restricted. Examples include Italy and Israel (Akirav 2014; Pedrazzani et al. 2018; Tuttnauer 2020). Even though the most obvious role of parliament is to legislate, in many countries such as Germany, the UK, Australia and Canada the government dominates the legislative process and initiates most bills (Hohendorf et al. 2021; Norton 2013; Wegmann 2020). Hence, the role of parliament has shifted and the ability to oversee the government has become a more important aspect of the parliamentary life of the individual legislator. For this reason, European scholars in particular have engaged in extensive investigations of parliamentary questions as a parliamentary tool. Given its presidential regime, the US House of Representatives does not have parliamentary questions, so its use has been of less interest to American scholars.

The studies about parliamentary questions have several themes. One is about the use of parliamentary questions to criticize and supervise the government's activities (Meijers and Van der Veer 2019; Vliegenthart and Walgrave 2011). A second theme is explanations of the differences in the number of parliamentary questions legislators ask, methods for selecting candidates, gender, changes in procedures, affiliation with the opposition, an increase in government activities and the size of the party (Höhmann and Sieberer 2019; Mugge et al. 2019; Saalfeld and Bischof 2013; Vliegenthart and Walgrave 2011). For example, Höhmann and Sieberer (2019) argued that government parties can use parliamentary questions to monitor coalition partners in order to reduce agency loss through ministerial drift. The third theme is the use of parliamentary questions as a ploy by the individual legislator for reelection and the role of the constituency for this end (Saalfeld 2011; Zittel et al. 2019). For example, Zittel et al. (2019) noted that legislators competing in more volatile constituencies are more likely to pose written questions containing geographic references.

Finally, the fourth theme deals with the way legislators use parliamentary questions as a reaction to issues raised in the media (Belchior 2020; Van Santen et al. 2015; Vliegenthart and Walgrave 2011).

Two additional non-legislative tools that have garnered less research attention are motions for the agenda (in Israel) or early day motions (in the UK) or motions (in Australia and Canada) (we will call all of them motions) and one-minute 
speeches (in the US, Canada, Australia and Israel). The first and major reason for this lack of interest is because these tools exist in just a handful of countries. The second reason is that both tools are considered even easier to use than parliamentary questions and definitely easier than legislation because they have minimal constraints, making them interesting to investigate.

Motions are the most neglected non-legislative tool in the legislative research field. In fact, most of the studies about them come from the UK. Only a few are about Israel (Akirav 2021). Other research has dealt with them as part of the analysis of speeches in general (Proksch and Slapin 2015), or in specific settings such as studies about motions in the Canadian parliament (Godbout and Høyland 2011; Godbout and Smaz 2016). For example, Godbout and Høyland (2011) analyzed private member motions, but included general motions and bills introduced by private members. They found a significant increase in the number of motions from the $38^{\text {th }}$ parliament to the $39^{\text {th }}$ parliament (from 39 to 111 , respectively). Godbout and Smaz (2016) documented that whenever the legislative agenda contained private members' motions related to regional issues, legislators were more likely to act independently. Hence, systematically these motions have been associated with lower levels of party unity.

Akirav (2021) analyzed the agenda power of the non-legislative tool motions for the agenda in the Israeli parliament. She defined this power as the ability to block or significantly delay motions from being debated in committee. She found that opposition legislators utilize these non-legislative tools more extensively than coalition members to wield their agenda power.

The studies that analyzed motions in the UK parliament dealt with three issues: their use as a tool for measuring legislators' opinions, the use of various research methodologies to measure early day motions (EDMs) and the providing of explanations about the way legislators use such motions (Bailey and Nason 2008; Kellermann 2012, 2013; Kolpinskaya 2016). Scholars have argued that legislators use EDMs for publicizing their views and drawing attention to specific events. They determined that the main users of EDMs are opposition legislators and backbenchers of the government. Furthermore, since initiating EDMs and supporting signatures for EDMs are un-whipped, they can be an indication of what the legislators truly believe and their opinions on issues they want to set on their agenda (Norton 2013). However, although a legislator can freely and spontaneously sign an EDM, strong party discipline is still enforced (Bailey and Nason 2008).

One-minute speeches (OMSs) are in use only in the US House of Representatives and the Israeli, Canadian and Australian parliaments, but the research on this tool has concentrated mainly on the US. Studies looked at how legislators use OMSs (Hughes 2018; Pearson and Dancey 2011). Explanations for the number of OMSs have posited that they are most frequent among institutionally disadvantaged legislators, ideologically extreme legislators and legislators who are members of minority parties (Hughes 2018; Pearson and Dancey 2011). Several other studies have considered the content of OMSs as part of the parliamentary debate (Bäck and Debus 2016; Pearson and Dancey 2011; Proksch and Slapin 2015).

Scholars agree that because of the unrestricted content and short length of OMSs they are an attractive communication tool for individual legislators and the party leadership (Bäck and Debus 2016; Green 2015; Pearson and Dancey 2011). Scholars investigating the Canadian parliament have noted two trends. Blidook (2013) found an increase in the number of OMSs between 2001 and 2012 (22,248 in total). Sotiropoulos (2009) demonstrated a change in the content of OMSs in Canada. In the past they were used by legislators for non-partisan purposes and dealt with the passing of prominent Canadians, international, national, provincial and local events, and constituency events. In recent times, however, there has been a change in the tone of OMSs and a more coordinated attempt to use them for strategic political gain. Blidook (2013) claimed that OMSs can be considered "institutional safety valves" - meaning that these venues relieve pressure by allowing individual legislators an outlet through which to express themselves, speak to local or specialized interests, and break away from the partisan control that exists in many other activities in which they must engage. However, Sotiropoulos $(2009,14)$ argued that the transformation of this minor and non-partisan part of the parliamentary day into a hyper-antagonistic period with no holds barred cannot, in the long run, be good for the institution of parliament or for the people it is supposed to represent.

As we can see, most previous studies have analyzed each legislative and non-legislative tool separately. They also emphasized the pivotal role of these taxonomies. I argue that looking at their use together can provide us with a comprehensive understanding of the legislators' strategic use of legislative and non-legislative tools. Legislators use them simultaneously and analyze the costs and benefits of each one of them on a daily basis. Hence, we need to look at the use of both legislative and non-legislative tools by a legislator in a given country with its unique procedures and electoral system.

In the next section I will analyze the procedures for each legislative and non-legislative tool and present three categories into which they fall based on the degree of constraint involved in their use: unconstrained (light procedures), 
semi-constrained (medium procedures) and fully constrained (heavy procedures).

\subsection{The Procedures of Legislative and Non-Legislative Tools ${ }^{l}$}

Every parliament has its rules of procedure with regard to the way it acts. Krehbiel (1992) defined legislative organization as "the allocation of resources and assignment of parliamentary rights to individual legislators or groups of legislators" (p. 2). Sorace (2018) argued that legislative activities differ in the degree to which they impose participation costs on individual legislators. Procedures can shape the ability of legislators to take a position, oversee the government and set an agenda (Cox and McCubbins 2005; Koger 2003). Therefore, it is important to understand the obstacles, quotas and limitations legislators face when they want to use legislative or non-legislative tools.

\subsubsection{The Legislative Process}

The legislative process consists of three major stages: presenting or sponsoring bills, the process of legislation in committees and on the floor and, finally the passage of legislation.

\section{Presenting and sponsoring bills}

In most parliaments, legislators have the right to introduce bills. However, there are countries such as Germany in which the right to initiate legislation from within parliament lies in the hands of parliamentary party groups or groups of legislators comprising at least five percent of the legislators (Wegmann 2020). Scholars agree that in most cases bills can be introduced with no serious intention of formulating and enacting new legislation or influencing government legislation. Rather, they are principally a means of profiling the legislator and/or his or her party (Bowler 2010; Brunner 2012).

Tables 1 lists the procedures of all five countries with regard to proposing a bill. It indicates whether there are limits on the content and number of bills that can be introduced as well as any special procedures.

Table 1. Procedures for proposing private members' bills

\begin{tabular}{|l|l|l|l|}
\hline & Content limitation & Quota limitation & $\begin{array}{l}\text { Special procedure for } \\
\text { private member's bills }\end{array}$ \\
\hline The UK & $\begin{array}{l}\text { Bills may not include financial } \\
\text { provisions unless the Member } \\
\text { has sought and been granted a } \\
\text { royal recommendation }\end{array}$ & Yes & $\begin{array}{l}\text { Four channels for } \\
\text { proposing a bill. }\end{array}$ \\
\hline Canada & $\begin{array}{l}\text { Bills may not include financial } \\
\text { provisions unless the Member } \\
\text { has sought and been granted a } \\
\text { royal recommendation. }\end{array}$ & None & None \\
\hline Australia & $\begin{array}{l}\text { Bills may not include a tax or } \\
\text { require the appropriation of } \\
\text { revenue or money. }\end{array}$ & None & None \\
\hline Israel & $\begin{array}{l}\text { None } \\
\text { But if the legislation is racist or } \\
\text { denies the existence of the } \\
\text { State of Israel, it will not be } \\
\text { approved. }\end{array}$ & None & None \\
\hline
\end{tabular}

\section{Hearings on the floor and in committee}

In all legislatures there are two arenas for the legislative process: the floor and the committees. In both the time devoted to private legislation is limited. Therefore, the tactical use of time in the bargaining process and the power of political actors in agenda setting are crucial (Bräuninger et al. 2017; Rosenthal 2018). Hence, the part of the legislative process that involves floor and committee debates and voting is challenging, because individual legislators need to convince other

1 Parliaments' websites were the sources used to create a framework for their degree of constraint and visibility. 
legislators including the committee chairs of the relevant committee to vote in favor of the bill. It is a never-ending negotiation process and depends on the legislators' ability to create ad-hoc coalitions (Rosenthal 2018).

Scholars agree that committees are critical parts of the organization of most legislatures. Therefore, it is important to understand the way they work and influence parliamentary behavior (Halligan and Reid 2016; Rosenthal 2018). For example, Halligan and Reid (2016) found that the conditions of the hung parliament in Australia between 2010 and 2013 significantly increased the level of dissent in the committees of the House of Representatives. While in Australia, Canada, Israel and the UK bills are not considered by committees prior to the plenary stage, in the US a bill is assigned to a committee for study. In Australia the committee does not have the right to amend the bill, while in Canada, Israel and the US it does. Cox and McCubbins (2005) regard legislative committees as the instruments of the majority party and its leadership.

The final hearing that leads to the passage of a bill faces the same obstacle mentioned previously-time. In the US House of Representatives and in the UK parliament legislators must pass legislation during that session of parliament. Hence, all bills not enacted by the end of the Congressional session die, and Congress starts over. ${ }^{2}$ In the Israeli parliament if a bill passed its first hearing and the session ended, under the continuousness rule legislators who were re-elected can ask to continue to promote the bill from its last stage. In Canada legislators can re-introduce a bill in the following sessions if they are re-elected.

After the passage of the law, in each of the countries additional signatures are needed. In Israel, the UK, Australia and Canada it is a formal signature: The Queen in the UK, the Governor General in the name of Her Majesty in Canada and in Australia, and the President in Israel. In the US the president has the power to sign the bill or to return it to Congress within 10 days with comments and without a signature, meaning it is vetoed. The Congress can override the president's veto with a vote of two thirds of the members.

Table 2 lists the procedures of all five countries for passing a bill with regard to the time limitations involved, the houses that must pass the bill, the type of majority vote and the final signatures required.

Table 2. Procedures for passing private members' bills

\begin{tabular}{|l|l|l|l|l|}
\hline & Time limitation & Legislative process & Type of majority vote & Final approval of the law \\
\hline The UK & During 10 Friday days & Both Houses & Simple majority & Formal \\
\hline Canada & $\begin{array}{l}\text { An hour per } \\
\text { parliamentary business } \\
\text { day for private } \\
\text { members' business }\end{array}$ & Both Houses & Majority of Members & Formal \\
\hline Australia & Mondays' debates & Both Houses & Majority of Members & Formal \\
\hline The US & $\begin{array}{l}\text { The bill must passed } \\
\text { within two years of the } \\
\text { House term }\end{array}$ & Both Houses & Majority of Members & $\begin{array}{l}\text { The President has the } \\
\text { ability to veto the bill }\end{array}$ \\
\hline Israel & None & The only House & Simple majority & Formal by the president \\
\hline
\end{tabular}

As Table 2 demonstrates, it is harder to pass private legislation in the UK, Canada and Australia than in the US and Israel. Indeed, previous studies indicate that governments dominate the legislative process and have a high success rate in passing bills. However, individual legislators also initiate a significant number of bills (Brunner 2012; Friedman and Friedberg 2021; Russell et al. 2016).

The number of private members' bills introduced annually varies considerably among countries, but the number of such bills that are passed is invariably quite small (Norton 2013).

\subsubsection{Parliamentary Questions}

The procedures relevant to parliamentary questions vary. Hence, scholars have suggested several approaches to comparing the procedures, one of which is distinguishing between open access or restricted access to questioning. For example, in the Norwegian Storting, access to written parliamentary questions (WPQs) is relatively open (Rasch 2011),

\footnotetext{
${ }^{2}$ Any member of Congress may introduce a bill at any time while the House is in session by placing it in the hopper on the Clerk's desk.

${ }^{3}$ After committee and delegation business in the House and Federation Chamber on Mondays, debate takes place on private members' business, that is, bills (proposed laws) and motions sponsored by private members.

4 Unless the bill involves an expenditure of more than 5 million new shekels. If it does, then 50 members have to vote yes.
} 
similar to the free and unlimited access of WPQs in the UK parliament (Norton 2013). In contrast, in Israel, Canada and Australia, WPQs have quotas (by faction or by individual legislator). As Soroka et al. (2009) noted, oral parliamentary questions (OPQs) are an example of individual legislative behavior, and are driven by a combination of procedural, institutional and party factors, constituency interests, and electoral instability.

Another dimension that distinguishes parliamentary questions is how far in advance they need to be submitted. For example, in the Netherlands, France, the UK, Canada, Sweden and Australia there is no obligation to present OPQs to a minister before the debate on the floor (Van Santen et al. 2015). In contrast, in Israel, Austria, Sweden and Belgium, legislators must submit WPQs in advance (Akirav 2014; Green-Pedersen 2010; Viliegenthart and Walgrave 2011). The amount of time legislators need to invest in order to formulate and ask questions is very short, and the procedures are more immediate compared to the legislative process. The main benefit is the fact that legislators can force ministers to check or reveal information, policies and actions they do not always want to share. While some questions are genuinely seeking information or action, others are designed to highlight the alleged shortcomings of the minister's department or the merits of an alternative policy. Legislators also use WPQs in order to extract more detailed information from the government than would be available from an oral question (Otjes and Louwerse 2018).

Table 3 lists the similarities and differences in five characteristics regarding the use of parliamentary questions.

Table 3. Five characteristics of parliamentary questions by country

\begin{tabular}{|l|l|l|l|l|l|l|}
\hline & & $\begin{array}{l}\text { Time limitation } \\
\text { for answering } \\
\text { the questions }\end{array}$ & $\begin{array}{l}\text { Individual or } \\
\text { faction quota }\end{array}$ & $\begin{array}{l}\text { How far in } \\
\text { advance } \\
\text { questions } \\
\text { need to be } \\
\text { submitted }\end{array}$ & $\begin{array}{l}\text { Quota } \\
\text { limitation }\end{array}$ & Answer arena \\
\hline \multirow{5}{*}{ The UK } & WPQs & None & Individual & $\begin{array}{l}\text { Pre } \\
\text { submission }\end{array}$ & None & Notice Paper \\
\cline { 2 - 7 } & OPQs & Yes & Individual & None & Yes & On the floor \\
\cline { 2 - 7 } & $\begin{array}{l}\text { Urgent } \\
\text { Question } \\
\text { (UPQs }\end{array}$ & Yes & Individual & $\begin{array}{l}\text { Pre } \\
\text { submission }\end{array}$ & Yes & On the floor \\
\hline Canada & WPQs & Yes & Individual & $\begin{array}{l}\text { Pre } \\
\text { submission }\end{array}$ & Yes & Notice Paper \\
\cline { 2 - 7 } & OPQs & Yes & Faction & None & Yes & On the floor \\
\cline { 2 - 7 } & OPQs & Yes & Individual & $\begin{array}{l}\text { Pre } \\
\text { submission }\end{array}$ & None & Notice Paper \\
\hline \multirow{4}{*}{ Israel } & WPQs & Yes & Individual & None & Yes & On the floor \\
\cline { 2 - 7 } & OPQs & Yes & Individual & $\begin{array}{l}\text { Pre } \\
\text { submission } \\
\text { submission }\end{array}$ & Yes & On the floor \\
\cline { 2 - 7 } & $\begin{array}{l}\text { Direct } \\
\text { Question }\end{array}$ & Yes & Individual & $\begin{array}{l}\text { Pre } \\
\text { submission }\end{array}$ & Yes & $\begin{array}{l}\text { Written answer } \\
\text { directly to the } \\
\text { legislator }\end{array}$ \\
\hline
\end{tabular}

As Table 3 demonstrates, in most countries parliamentary questions are public and result from individual initiation. Ministers must answer the questions within a short period of time and there is no need for pre-submission. Hence, as previous scholars indicated about OPQs in Canada, the UK and Australia, they are an example of individual legislative behavior, and are driven by a combination of procedural, institutional and party factors, constituency interests, and electoral instability (Kellermann 2016; Soroka et al. 2009; Van Santen et al. 2015). As Franks (1985) argued, the question period in the UK is sophisticated, and frequently clever, but it is rarely as spontaneous or dynamic as in the Canadian parliament.

\subsubsection{One-Minute Speeches}

As opposed to legislation and parliamentary questions, in the case of OMSs the procedures are almost the same in four

\footnotetext{
${ }^{5}$ A member may indicate that he or she wishes to receive an oral reply to a question during routine proceedings by marking the written question with an asterisk at the time it is submitted.
} 
countries (the US, Israel, Canada and Australia). Table 4 lists the similarities and differences in four characteristics regarding the use of OMSs.

Table 4. Four characteristics of one-minute speeches by country

\begin{tabular}{|l|l|l|l|l|}
\hline & Time limitation & Content limitation & Quota limitation & Participant limitations \\
\hline Canada & Yes & None & None & Excluding ministers \\
\hline Australia & Yes & None & None & Excluding ministers \\
\hline The US & Yes & None & None & Not Relevant \\
\hline Israel & Yes & None & None & Including ministers and deputy ministers \\
\hline
\end{tabular}

As Table 4 demonstrates, the time constraint refers to the length of the speech (60-90 seconds), but there is no quota limitation or content limitation. Hence, on a weekly basis any individual legislator may speak.

\subsubsection{Motions}

As noted previously, motions ${ }^{6}$ are the most neglected non-legislative tool in the field of legislative research. However, legislators use it mainly for publicizing their views and drawing attention to specific events (Akirav 2021; Kellermann 2012; Kolpinskaya 2016). As Table 5 shows, motions are an easy non-legislative tool to use, but most of them are just for the record.

Table 5. Procedures for motions

\begin{tabular}{|l|l|l|l|l|}
\hline & Time limitation & $\begin{array}{l}\text { Content } \\
\text { limitation }\end{array}$ & Quota limitation & $\begin{array}{l}\text { On the Record or } \\
\text { Public }\end{array}$ \\
\hline The UK & Yes & Yes & None & On the Record \\
\hline Canada & Yes & Yes & Partial & On the Record \\
\hline Australia & Yes & Yes & None & $\begin{array}{l}\text { Public and On the } \\
\text { Record }\end{array}$ \\
\hline Israel & Yes & Yes & Yes & Public $^{8}$ \\
\hline
\end{tabular}

The two main differences in the motions between the countries are quota limitations and publicity (whether the motions are just on the record or on the floor). Indeed, Franks (1985) referred to motions as the worst attended and worst reported parliamentary events. Nevertheless, as an additional parliamentary tool for individual legislators, they can be used for position taking, as Mayhew suggested.

\subsection{Constraints on the Use of Legislative and Non-Legislative Tools}

I categorized these legislative and non-legislative tools into three groups based on the degree of constraint involved in using them: unconstrained (light procedures), semi-constrained (medium procedures) and fully constrained (heavy procedures). Table 6 presents the legislative and non-legislative tool in each country by their degree of constraint.

Table 6. Fully constrained, semi-constrained and unconstrained parliamentary tools by country

\begin{tabular}{|c|c|c|}
\hline Unconstrained & Semi-constrained & Fully constrained \\
\hline Proposing a bill (Israel, the US, & WPQs (Israel) & Proposing a bill (UK) \\
\hline WPQs (UK) & $\begin{array}{l}\text { OPQs (Israel, the UK, Canada } \\
\text { and Australia) }\end{array}$ & $\begin{array}{l}\text { Floor and committee hearings (UK, US, } \\
\text { Israel, Canada and Australia) }\end{array}$ \\
\hline $\begin{array}{l}\text { OMSs (US, Israel, Canada and } \\
\text { Australia) }\end{array}$ & UPQs (UK) & $\begin{array}{l}\text { The passage of bills (UK, US, Israel, Canada } \\
\text { and Australia) }\end{array}$ \\
\hline $\begin{array}{l}\text { Motions (UK, Canada and } \\
\text { Australia) }\end{array}$ & Motions (Israel) & \\
\hline
\end{tabular}

OMSs which exist in the US House of Representatives and the Australian, Canadian and Israeli parliaments, are considered unconstrained tools that legislators can use during the specific time scheduled by the Speaker. The decision to use them is entirely in the hands of the legislators who are the only ones who decide their content. Another unconstrained non-legislative tool is WPQs in the UK parliament. Similar to early day motions, legislators can ask as many questions as

\footnotetext{
6 Motions that are not part of the legislative process.

${ }^{7}$ A motion may have up to 20 seconders (a member who wishes to support a motion already appearing on the record).

8 If the legislator is not present at the time his/her motion is on the floor, the question and its answer are presented only on the floor protocol.
} 
they want.

Semi-constrained non-legislative tools generally limit the number legislators can use, but the procedure is not complicated. For example, in the Israeli parliament there is a quota on the number of WPQs each legislator can ask (30 per year), but the legislators decide whether to use them and what their content will be. In the UK parliament UPQs have no quotas, but the Speaker decides whether the question is urgent and whether it will be asked on the floor.

Unconstrained or semi-constrained legislative or non-legislative tools occur as one event (at one specific time on the floor or written in the records), while fully constrained legislative tools, which are mainly legislation, involve a process that occurs in several arenas in parliament and over a long period of time. Thus, legislation requires legislators to overcome not just procedural obstacles, but also to cooperate with other legislators in order to pass laws. In the UK, Australian and Canadian parliaments, it is very hard for individual legislators to propose and pass legislation, whereas in the US House of Representatives and the Israeli parliament it is possible.

\subsection{Visibility of the Tool}

After determining the level of constraint for each legislative and non-legislative tool in each parliament, we need to consider one more characteristic--whether the tool is in the eye of the public (visibility) or appears only on parliamentary records. This point is important if we agree with Strøm's (1997) strategic approach that legislative roles describe the ways in which legislators harness their scarce resources in order to reach their goals. These strategies are in turn affected by the institutional rules under which legislators operate. Hence, parliamentary behavior can be understood against the background of four typical objectives that legislators have: reselection or re-nomination, reelection, the attainment of party office, and the attainment of legislative office. In order to achieve these goals legislators' legislative and non-legislative activities need to be in the public eye. Table 7 lists each tool by its degree of publicity and level of constraint.

Table 7. Legislative and non-legislative tools by degree of constraint and visibility

\begin{tabular}{|l|l|l|l|}
\hline Public & Unconstrained & Semi-constrained & Fully constrained \\
& $\begin{array}{l}\text { Proposing a bill } \\
\text { (Israel, US, Canada, } \\
\text { Australia) }\end{array}$ & WPQs (Israel) & Proposing a bill (UK) \\
& $\begin{array}{l}\text { OPSs (US, Israel, } \\
\text { Canada, Australia) }\end{array}$ & UPQ(UK) \\
Motions (Australia) & Motions (Israel) & $\begin{array}{l}\text { Floor and committee } \\
\text { hearings (UK, US, } \\
\text { Israel, Australia, } \\
\text { Canada) }\end{array}$ \\
\hline On the record & $\begin{array}{l}\text { WPQs (UK) } \\
\text { Motions (UK, Canada } \\
\text { and Australia) }\end{array}$ & $\begin{array}{l}\text { The passage of bills } \\
\text { (UK, US, Israel, } \\
\text { Australia, Canada) }\end{array}$ \\
\hline
\end{tabular}

Based on the analysis of legislative and non-legislative tools in all five countries we can see that OMSs, presenting a bill and passing a bill are in the public eye. Motions are on the record in three countries (the UK, Australia and Canada) and public in two countries (Israel and Australia ${ }^{9}$ ). Finally, parliamentary questions vary depending on the kind of question. WPQs are public only in Israel while they are on the record in the UK, Australia and Canada. OPQs are public in all parliaments and so are UPQs in the UK.

Based on this discussion, I hypothesize that:

H1: Legislators from Australia, the UK and Canada will use fewer legislative tools than legislators from Israel and the US due to the degree of constraint involved in their use.

$\mathrm{H}$ 2: Legislators will use more semi or unconstrained tools that are reported to the public than semi or unconstrained tools that appear just on the record.

\subsection{The Benefits of Using Legislative and Non-Legislative Tools}

When legislators are part of the majority party, they are better able to advance their agenda or achieve their goals than when they are part of the opposition. Hence, membership in the majority party is often considered an important factor in explaining legislative and non-legislative activity (Friedman and Friedberg 2021; Green 2015; Kellermann 2016; Miquel

\footnotetext{
${ }^{9}$ In Australia they can be public and on the record.
} 
and Snyder 2006). Green (2015) disputed the claim that the minority party in the US House of Representatives has little or no legislative influence. He offered empirical evidence of their important role in passing or blocking controversial legislation, often through active floor protests, press conferences, obstructionism, and other means. Scholars have established that US legislators from the majority party who consistently sponsor bills are more successful in the legislative process than minority party members (Garand and Burke 2006; Kirkland and Kroeger 2018).

Research has also established that opposition legislators make far more use of non-legislative tools, especially parliamentary questions (Jensen et al. 2013; Kolpinskaya 2016; Saalfeld 2011). Kolpinskaya (2016) documented that opposition UK legislators present more WPQs on issues of concern to minorities than legislators from the party of the government. In the Canadian parliament, government cabinet legislators and government backbenchers ask fewer OPQs than opposition backbenchers and opposition shadow cabinet legislators (Soroka et al. 2009). Finally, in Austria, legislators from the coalition are much less inclined to introduce parliamentary questions than those from opposition parties (Jenny and Müller 2012).

Parliamentary questions provide a venue in which opposition parties can hold the government to account, criticize government policies and suggest alternatives, gain experience, and demonstrate their potential as alternatives to the current government (Kellermann 2016; Zittel et al. 2019).

Even in the studies about the neglected non-legislative tools-OMSs and motions --- scholars have established that opposition members use them more often (Akirav 2021; Kellermann 2012; Sotiropoulos 2009). For example, Kellermann (2012) found that two types of early day motions would typically be introduced: one consistent with the policy preferences of the rebels and another consistent with the preferences of the opposition.

This review of the literature demonstrates that most studies have investigated the use of legislative and non-legislative tools separately. What insights are revealed when we examine their use simultaneously?

I posit that such an investigation will reveal that:

H3: Opposition members use non-legislative tools more frequently, whereas members of the government use more legislative tools more frequently. The degree of constraint involved in the use of the tool will moderate this frequency.

\section{Methodology}

In order to examine the hypotheses, I chose five Western democracies: ${ }^{10}$ the US, the UK, Australia, Canada and Israel. For each country I gathered data on three full parliamentary terms ${ }^{11}$ and for each legislator I gathered the following data; the number of private member bills presented per day, ${ }^{12}$ the number of private member bills passed per day, the number of OPQs per day, the number of WPQs per day, the number of OMSs per day, the number of motions per day and the legislator's status as a member of the government or the opposition.

I collected the data from the website of each parliament using a data mining procedure. I did not include ministers, the Prime Minister, deputy ministers, the Speaker and legislators who served only part of the term, because I analyzed only those legislators who served a full term and did not have a position with more resources than an ordinary legislator.

\section{Results and Discussion}

In order to conduct a stepwise linear regression for each legislative and non-legislative tool, I created several dummy variables for each parliamentary term of each country ${ }^{13}$ and for majority (governing) party affiliation for each legislator.

\subsection{Legislative Tools}

Tables 8 and 9 present the results of multiple regressions used to predict the proposing and passage of a bill by parliamentary term

\footnotetext{
10 In the UK, US, Canada and Australia I examined the lower house. In Israel there is just one house.

${ }^{11}$ Australia 2007-2016, Canada 2006-2015, Israel 2006-2015, UK 2005-2017 and US 2009-2015.

12 I decided to measure the frequency of use of the legislative and non-legislative tools per day in order to overcome the different lengths of each term of each parliament.

13 See Appendix 1.
} 
Table 8. Results of multiple regressions to predict the proposing of a bill by parliamentary term

\begin{tabular}{|c|c|c|c|c|c|}
\hline \multirow{2}{*}{ Predictors } & & & & \multirow[b]{2}{*}{$\mathrm{T}$} & \\
\hline & $\mathrm{B}$ & SE B & $\beta$ & & \\
\hline Israel3 & 0.563 & 0.010 & 0.599 & $56.776 * * *$ & \\
\hline Israel2 & 0.344 & 0.011 & 0.341 & $32.318 * * *$ & \\
\hline Israel1 & 0.221 & 0.010 & 0.223 & $21.169 * * *$ & \\
\hline US2 & 0.062 & 0.005 & 0.146 & $13.608 * * *$ & \\
\hline US1 & 0.059 & 0.005 & 0.140 & $13.071 * * *$ & \\
\hline US3 & 0.053 & 0.005 & 0.125 & $11.682 * * *$ & \\
\hline $\mathrm{R}^{2}$ & & & & & .513 \\
\hline$F$ & & & & & $774.224 * * *$ \\
\hline
\end{tabular}

Table 9. Results of multiple regressions to predict the passing of a bill by parliamentary term

\begin{tabular}{|c|c|c|c|c|c|}
\hline \multirow[t]{2}{*}{ Predictors } & & & & \multirow[b]{2}{*}{$\mathrm{T}$} & \\
\hline & B & SE B & $\beta$ & & \\
\hline Israel3 & 0.044 & 0.001 & 0.649 & $63.219 * * *$ & \\
\hline Israel2 & 0.023 & 0.001 & 0.317 & $30.931 * * *$ & \\
\hline Israel1 & 0.014 & 0.001 & 0.205 & $19.947 * * *$ & \\
\hline Governing party & 0.001 & 0.000 & 0.065 & $6.353^{* * * *}$ & \\
\hline US1 & 0.002 & 0.000 & 0.077 & $7.433 * * *$ & \\
\hline US3 & 0.002 & 0.000 & 0.065 & $6.221 * * *$ & \\
\hline US2 & 0.002 & 0.000 & 0.061 & $5.845 * * *$ & \\
\hline $\mathrm{R}^{2}$ & & & & & .544 \\
\hline$F$ & & & & & $750.503 * * *$ \\
\hline
\end{tabular}

The first and most significant finding is that the degree of constraint of the tool is important. Israeli and US legislators present more bills while UK, Australian and Canadian legislators do not. This finding accords with previous studies. When the procedures to present bills are unconstrained, legislators present more bills compared to other countries where the procedures are semi or fully constrained (Hohendorf et al. 2021; Norton 2013; Tuttnauer 2020). Fifty-one percent of the explanation for the number of bills presented is the country (Israel and the US as opposed to the UK, Australia and Canada). These results confirm Hypothesis 1 that legislators from Australia, the UK and Canada use fewer legislative tools than those from Israel and the US because of its degree of constraint involved in their use.

The second interesting finding is with regard to the passage of bills. Once again, legislators from Israel and the UK pass more bills than legislators from the US, Canada and Australia. Even though the legislative process is constrained in all five countries, legislators from Israel and the US manage to overcome them. It is important to note that, as previous studies found, the party plays an important role in the legislative process in the UK, Canada and Australia (e.g., Bowler 2010; Döring 2017; Godbout and Høyland 2011). The findings strengthen this point by comparing five different countries with regard to the role that party the plays in them.

\subsection{Non-Legislative Tools}

The second research hypothesis posited that legislators use more semi or unconstrained non-legislative tools that are publicly visible than those that are simply on the record.

\subsubsection{One-Minute Speeches}

Table 10 presents the results of multiple regressions to predict the use of OMSs. As the table illustrates, the use of OMSs is positive in all three terms in Canada and the latest term in Australia. In contrast, in Israel, the second US term and the first term in Australia it is negative. 
Table 10. Results of multiple regressions to predict the use of one-minute speeches

\begin{tabular}{|c|c|c|c|c|c|}
\hline \multirow[t]{2}{*}{ Predictors } & & & & \multirow[b]{2}{*}{$\mathrm{t}$} & \\
\hline & $\mathrm{B}$ & SE B & $\beta$ & & \\
\hline Australia3 & 0.094 & 0.007 & 0.265 & $14.098 * * *$ & \\
\hline Canada1 & 0.024 & 0.005 & 0.096 & $4.963 * * *$ & \\
\hline Canada2 & 0.022 & 0.005 & 0.088 & $4.556^{* * *}$ & \\
\hline Canada3 & 0.020 & 0.005 & 0.081 & $4.226 * * *$ & \\
\hline Israel1 & -0.032 & 0.008 & -0.072 & $-3.855^{* * *}$ & \\
\hline Australia1 & -0.025 & 0.007 & -0.070 & $-3.703 * * *$ & \\
\hline US2 & -0.011 & 0.004 & -0.055 & $-2.795^{*}$ & \\
\hline Governing party & -0.007 & 0.003 & -0.048 & $-2.608^{*}$ & \\
\hline $\mathrm{R}^{2}$ & & & & & .106 \\
\hline$F$ & & & & & $40.613 * * *$ \\
\hline
\end{tabular}

OMS are an unconstrained non-legislative tool whose use is publicly noted. Canadian legislators use it much more extensively than their counterparts in other parliaments. As previous studies have noted, Canadian legislators increased their use of this tool between 2001 and 2012 (Blidook 2013). In addition, Canadian legislators have made more coordinated attempts to use them for strategic political gain (Sotiropoulos 2009). OMSs also enable legislators to speak about local or special interests, and break away from the partisan control that exists in many other activities in which they must engage (Blidook 2013). The findings strengthen the few previous studies regarding the Canadian parliament.

As opposed to previous studies regarding the US House of Representatives, when comparing the use of OMSs with other countries that use it too, the frequency of use is lower (Hughes 2018; Pearson and Dancey 2011). These results confirm Hypothesis 2 with respect to the use of OMSs which is an unconstrained, public tool.

\subsubsection{Oral Parliamentary Questions}

In all parliaments OPQs are public and semi-constrained. They were used in Canada and Israel in all three terms and in the UK in one term. However, in Canada their use is positive, while in Israel and in UK it is negative. This finding accords with Soroka et al. (2009) who claimed that OPQs are an example of individual legislative behavior and that the question period is the most visible part of the Canadian parliamentary process. This finding also strengthens the claim that the question period in the UK is sophisticated, and frequently clever, but it is rarely as spontaneous or dynamic as that in the Canadian parliament (Franks 2016). The findings do not accord with previous studies regarding the frequent use of OPQs in the UK (Saalfeld 2011). The more frequent use of OPQs in Canada compared to the other countries, including the UK, shows that individual Canadian legislators regard it as an appropriate tool. From Soroka et al.'s (2009) point of view, OPQs provide the Canadian legislator with the opportunity to take a position on a given issue publicly.

Table 11 presents the results of multiple regressions predicting the use of oral parliamentary questions by parliamentary term

Table 11. Results of multiple regressions to predict the use of oral parliamentary questions

\begin{tabular}{|c|c|c|c|c|c|}
\hline \multirow[t]{2}{*}{ Predictors } & & & & \multirow[b]{2}{*}{$\mathrm{t}$} & \\
\hline & $\mathrm{B}$ & SE B & $\beta$ & & \\
\hline Canada3 & 0.121 & 0.015 & 0.147 & $8.287 * * *$ & \\
\hline Canada2 & 0.114 & 0.014 & 0.142 & $7.988 * * *$ & \\
\hline Canada1 & 0.096 & 0.014 & 0.118 & $6.660 * * *$ & \\
\hline Governing party & -0.044 & 0.008 & -0.096 & $-5.567 * * *$ & \\
\hline Israel3 & -0.117 & 0.025 & -0.082 & $-4.731 * *$ & \\
\hline Israel2 & -0.110 & 0.026 & -0.072 & $-4.168 * *$ & \\
\hline Israel1 & -0.107 & 0.026 & -0.071 & $-4.116^{* *}$ & \\
\hline UK1 & -0.043 & 0.011 & -0.073 & $-4.027 * * *$ & \\
\hline $\mathrm{R}^{2}$ & & & & & .0 .094 \\
\hline$F$ & & & & & $40.205 * * *$ \\
\hline
\end{tabular}

Since OPQ semi-constrained and public, Hypothesis 2 is confirmed. 


\subsubsection{Written Parliamentary Questions}

WPQs are on the record in three countries (the UK, Australia and Canada) while in Israel they are public. They were used extensively in all three parliamentary terms in the UK. In contrast, regardless of whether they are public or on the record, their use in other countries is not significant. Table 12 presents the results of multiple regressions to predict the use of WPQs by parliamentary term.

Table 12. Results of multiple regressions to predict the use of written parliamentary questions

\begin{tabular}{|c|c|c|c|c|c|}
\hline \multirow[t]{2}{*}{ Predictors } & & & & & \\
\hline & $\mathrm{B}$ & SE B & $\beta$ & $\mathrm{T}$ & \\
\hline UK3 & 0.611 & 0.033 & 0.328 & $18.525 * * *$ & \\
\hline UK1 & 0.597 & 0.034 & 0.315 & $17.800 * * *$ & \\
\hline UK2 & 0.453 & 0.033 & 0.246 & $13831 * * *$ & \\
\hline Governing party & -0.166 & 0.024 & -0.115 & $-6.938 * * *$ & \\
\hline $\mathrm{R}^{2}$ & & & & & .156 \\
\hline$F$ & & & & & $143.877 * * *$ \\
\hline
\end{tabular}

These results do not confirm Hypothesis 2 because the most frequent use of this non-legislative tool relates to an unconstrained tool that is only on the record. The results show that UK legislators prefer the unconstrained nature of the tool even if it is only on the record and not public. One explanation for this finding is that they can use their social media accounts to publicize it or use it as a reaction to issues raised in the media (Van Santen et al. 2015; Vliegenthart and Walgrave 2011). Hence, the public will see the content of their WPQs. Studies about the content of such questions document that legislators from minority groups write about issues of concern to minority groups (gender, religion, race). Similar behavior was found in countries other than the UK (Kolpinskaya 2017; Mügge et al. 2019).

\subsubsection{Motions}

Motions are on the record in three countries (Canada, the UK and Australia) and public in one (Israel), but were used significantly only in the latest parliamentary term in the UK.

Table 13 reports the results of multiple regressions predicting the use of motions by parliamentary term

Table 13. Results of multiple regressions predicting the use of motions

\begin{tabular}{|c|c|c|c|c|c|}
\hline \multirow[t]{2}{*}{ Predictors } & & & & & \\
\hline & B & SE B & $\beta$ & $\mathrm{t}$ & \\
\hline UK3 & 0.374 & 0.017 & 0.365 & $21.890 * * *$ & \\
\hline Governing party & -0.132 & 0.013 & -0.165 & $-10.033 * * *$ & \\
\hline $\mathrm{R}^{2}$ & & & & & .161 \\
\hline$F$ & & & & & $297.601 * * *$ \\
\hline
\end{tabular}

These results confirm Hypothesis 2, even though legislators preferred the use of an unconstrained tool that was only on the record and in just one parliamentary term. The question is why in the other countries do legislators make less use of motions? One explanation might be the fact that in most of the other countries except for Israel, it is only on the record. Another explanation is that there are other non-legislative tools such as OMSs and OPQs that are unconstrained or semi-constrained and public. Hence, legislators from Australia, Canada and Israel prefer to use them more. UK legislators do not have the non-legislative tool of OMSs to use in order to speak up and be heard, so their alternative non-legislative tool is motions.

To investigate whether there are paired uses of legislative and non-legislative tools in each country, I conducted a Pearson's correlation. The results appear in Table 14. Next to each significant result I indicated the type of visibility (public or on the record). 
Table 14. Legislative and non-legislative tools by country and publicity

\begin{tabular}{|c|c|c|c|c|c|}
\hline & Australia & Canada & Israel & UK & US \\
\hline $\begin{array}{c}\text { Bills } \\
\text { presented \& } \\
\text { Bills passed }\end{array}$ & $\begin{array}{c}\text { Pearson }=0.523, \text { sig }=0.00 \\
\text { Public \& Public }\end{array}$ & & $\begin{array}{l}\text { Pearson }=0.512, \\
\quad \text { sig }=0.00 \\
\text { Public \& Public }\end{array}$ & $\begin{array}{l}\text { Pearson }=0.126, \\
\quad \text { sig }=0.00 \\
\text { Public \& Public }\end{array}$ & $\begin{array}{c}\text { Pearson }=0.232, \\
\text { sig }=0.00 \\
\text { Public \& Public }\end{array}$ \\
\hline $\begin{array}{l}\text { Bills } \\
\text { presented \& } \\
\text { Motions }\end{array}$ & $\begin{array}{c}\text { Pearson }=0.131, \text { sig }= \\
0.015 \\
\text { Public \& Public }\end{array}$ & $\begin{array}{l}\text { Pearson }=0.272, \\
\quad \text { sig }=0.00 \\
\text { Public \& Public }\end{array}$ & $\begin{array}{l}\text { Pearson }=0.237, \\
\quad \text { sig }=0.00 \\
\text { Public \& Public }\end{array}$ & & \\
\hline $\begin{array}{c}\text { Bills } \\
\text { presented \& } \\
\text { WPQs }\end{array}$ & & $\begin{array}{l}\text { Pearson }=0.173, \\
\quad \text { sig }=0.00 \\
\text { Public \& Public }\end{array}$ & & $\begin{array}{l}\text { Pearson }=0.083, \\
\quad \text { sig }=0.001 \\
\text { Public \& Record }\end{array}$ & \\
\hline $\begin{array}{c}\text { Bills } \\
\text { presented \& } \\
\text { OPQs }\end{array}$ & & & & $\begin{array}{c}\text { Pearson }=0.168, \\
\text { sig }=0.00 \\
\text { Public \& Public }\end{array}$ & \\
\hline $\begin{array}{l}\text { Bills } \\
\text { presented \& } \\
\text { OMSs } \\
\end{array}$ & & & & & $\begin{array}{c}\text { Pearson }=0.1, \\
\text { sig }=0.001 \\
\text { Public \& Public }\end{array}$ \\
\hline $\begin{array}{l}\text { WPQs \& } \\
\text { OMSs }\end{array}$ & $\begin{array}{c}\text { Pearson }= \\
-0.122, \text { sig }=0.023 \\
\text { Public \& Public }\end{array}$ & & & & \\
\hline $\begin{array}{l}\text { WPQs \& } \\
\text { Motions }\end{array}$ & & $\begin{array}{c}\text { Pearson }=0.192, \\
\text { sig }=0.00 \\
\text { Record \& Record }\end{array}$ & $\begin{array}{c}\text { Pearson }=0.257, \\
\text { sig }=0.00 \\
\text { Public \& Public }\end{array}$ & & \\
\hline $\begin{array}{l}\text { WPQs \& } \\
\text { OPQs }\end{array}$ & & $\begin{array}{c}\text { Pearson }=0.098 \\
\text { sig }=0.006 \\
\text { Record \& Public }\end{array}$ & $\begin{array}{l}\text { Pearson }=0.477, \\
\text { sig }=0.00 \\
\text { Public \& Public }\end{array}$ & $\begin{array}{c}\text { Pearson }=0.203, \\
\text { sig }=0.00 \\
\text { Record \& Public }\end{array}$ & \\
\hline $\begin{array}{c}\text { OPQs \& } \\
\text { OMSs }\end{array}$ & & $\begin{array}{l}\text { Pearson }=0.179 \\
\text { sig }=0.00 \\
\text { Public \& Public }\end{array}$ & $\begin{array}{c}\text { Pearson }=0.16 \\
\text { sig=0.016 } \\
\text { Public \& Public }\end{array}$ & & \\
\hline $\begin{array}{l}\text { OPQs \& } \\
\text { Motions }\end{array}$ & & & $\begin{array}{l}\text { Pearson }=0.258, \\
\text { sig }=0.00 \\
\text { Public \& Public }\end{array}$ & $\begin{array}{l}\text { Pearson }=0.11, \\
\quad \text { sig }=0.00 \\
\text { Public \& Record }\end{array}$ & \\
\hline $\begin{array}{l}\text { OMSs \& } \\
\text { Motions }\end{array}$ & & & $\begin{array}{c}\text { Pearson }=0.37, \\
\quad \text { sig }=0.00 \\
\text { Public \& Public }\end{array}$ & & \\
\hline
\end{tabular}

There are 17 significant paired tools based on the fact that they are both public. However, non-legislative tools that are on the record were used too--once with another tool on the record and four times with another tool that is public.

Therefore, we can say that legislators use non-legislative tools first when they are public and second as an additional option to be heard when they are not in the public eye, but they are on the record.

Based on the entire discussion on the use of legislative and non-legislative tools, Hypothesis 2 was confirmed: legislators use more semi or unconstrained tools that are public than semi or unconstrained tools that are just on the record.

\subsection{Does Governing Party Position Matter?}

To test H3 that opposition members use non-legislative tools while government members use more legislative tools, moderated by the degree of constraint of the tool, I conducted a stepwise linear regression with all previous dummy variables and the addition of more one dummy variable for governing party. The findings are presented in Tables 8-13.

In the US (all three terms) and Israel (all three terms) being part of the governing party increases the probability of passing legislation (Beta $=0.065, \mathrm{t}=6.353$, sig=0.000).

The findings strengthen the argument that membership in the government helps promote the legislators' agenda (Friedman and Friedberg 2021; Miquel and Snyder 2006). Furthermore, in order to pass legislation a legislator needs the cooperation of his/her counterparts in every step of the legislative process. As government party members they can cooperate with other government party members or with opposition party members. Indeed, when the issue of the proposed bill is controversial, we expect the government-opposition conflict to be at its highest (Ganghof et al. 2019). However, when the issues are not controversial and pertain mainly to issues marginal to the general electorate, 
opposition members will vote in favor of bills initiated by government party members (Tuttnauer 2020). Wawro (2000) used the concept of legislative entrepreneurship to describe legislators' activities. In the US House of Representatives, creating coalitions that include members from the opposite party of the bill's imitator helps pass legislation by combining various legislative inputs and issues.

However, looking at the first stage of legislation-proposing a presenting bill -- there is no special benefit in being part of the government. The variable was not significant, which means that both government and opposition members propose bills in the same manner in Israel and the US.

Analysis of the simultaneous use of non-legislative tools reveals that they are used more by opposition members than government party members. Opposition members use the unconstrained, visible non-legislative tool - OMS - more frequently than government party members (Beta $=-0.048, \mathrm{t}=-2.608$, sig $=0.009)$. They also make more use of the semi-constrained, visible non-legislative tool - OPQs -- more frequently than government party members $($ Beta $=$ $-0.096, \mathrm{t}=-5.567, \mathrm{sig}=0.000)$. In addition, opposition members use the unconstrained, on the record non-legislative tool -- WPQs -- more frequently than government party members (Beta $=-0.115, \mathrm{t}=-6.938$, sig $=0.000$ ). Finally, opposition members use the unconstrained, on the record non-legislative tool -- motions -- more frequently than government party members (Beta $=-0.165, \mathrm{t}=-10.033 \mathrm{sig}=0.000$ ). These results confirm H3. They also strengthen previous studies that analyzed each non-legislative tool separately and found that they are used more extensively by opposition members in order to criticize the government (parliamentary questions) or to set their agenda and a take position (OMSs and motions) (Akirav 2021; Franks 2016; Kellermann 2012; Kolpinskaya 2016, 2017; Saalfeld and Bischof 2013).

\section{Summary}

Analyzing the use of both legislative and non-legislative tools simultaneously helps us understand the strategic behavior of legislators in the five countries presented in this article. In their daily lives, legislators conduct a cost-benefit analysis with regard to the degree of the constraint of each legislative and non-legislative tool and their visibility.

My findings strengthen the claim of scholars that procedures matter and can affect individual legislators' behavior (Cox and McCubbins 2005; Friedman and Friedberg 2021; Sorace 2018). Based on the analysis of the allocation of resources and the degree to which legislative and non-legislative activities impose participation costs on individual legislators (Sorace 2018), these legislators prefer unconstrained, public legislative and non-legislative tools, but they also use tools that are unconstrained or semi-constrained that are just on the record, as a second-best choice. In addition, the dominancy of the party is relevant too for the strategic use of legislative and non-legislative tools. In the UK, Canada and Australia the party plays a significant role in legislators' daily life while in Israel and the US, legislators can act outside the party line.

Having a variety of non-legislative tools is important for legislators because they allow them to represent their voters, speak up and set their agenda. If they are opposition members, it is even more crucial. The daily life in parliament is not just about legislation. In recent decades it has become more about the use of non-legislative tools. This study provides a more comprehensive picture of the cost-benefit analysis legislators face in their daily life across countries. Future studies should analyze more countries with different electoral systems. For example, Germany and Japan have a mixed electoral system, resulting in different incentives to use legislative and non-legislative tools within the same country. In both countries the legislative process is a fully constrained tool. In Germany the right to initiate legislation from within parliament lies in the hands of parliamentary party groups or groups of legislators comprising at least five percent of the legislators. In Japan such a bill must be co-sponsored by at least 20 members in the House of Representatives (Lower House) and at least 10 members in the House of Councillors (Upper House). A bill accompanying the budget must be co-sponsored by at least 50 members in the Lower House and at least 20 members in the Upper House.

Future studies should also analyze more countries with more than one non-legislative tool (Germany has only parliamentary questions, while Japan has motions and parliamentary questions). Finally, future studies should also interview legislators about their incentive to use legislative and non-legislative tools, in order to capture the story behind the scenes.

\section{References}

Akirav, O. (2014). What do representatives produce? Work profiles of representatives. Party Politics, 22(3), 289-299. https://doi.org/10.1177/1354068814549344

Akirav, O. (2021). The agenda power of non-legislative tools. Israel Affairs, 27(2), 351-369. https://doi.org/10.1080/13537121.2021.1891507

Bäck, H., \& Debus, M. (2016). Political parties, parliaments and legislative speechmaking. Springer.

Bailey, D., \& Nason, G. P. (2008). Cohesion of Major Political Parties. British Politics, 3, 390-417. 
https://doi.org/10.1057/bp.2008.10

Belchior, A. M. (2020). Media, public opinion and parliamentary agendas' effect in political parties' agenda-setting. The Agenda Setting Journal, 4(1), 17-42. https://doi.org/10.1075/asj.19008.bel

Blidook, K. (2013). The Changing Use of Standing Order 31 Statements. Canadian Parliamentary Review, 36(4), 25.

Bowler, S. (2010). Private members' bills in the UK parliament: Is there an 'electoral connection'? The Journal of Legislative Studies, 16(4), 476-494.

Bräuninger, T., Debus, M., \& Wüst, F. (2017). Governments, parliaments and legislative activity. Political Science Research and Methods, 5(3), 529.

Brunner, M. (2012). Parliaments and Legislative Activity: Motivations for Bill Introduction. Springer Science and Business Media.

Cox, G. W., \& McCubbins, M. D. (2005). Setting the agenda: Responsible party government in the US House of Representatives. Cambridge University Press.

Dassonneville, R., Hooghe, M., \& Lewis-Beck, M. S. (2017). Do electoral rules have an effect on electoral behaviour? An impact assessment. West European Politics, 40(3), 503-515.

Döring, H. (2017). Patterns of parliamentary behavior: Passage of legislation across Western Europe. Routledge.

Franks, C. E. S. (1985). Debates and question period in the Canadian House of Commons: What purpose do they serve? American Review of Canadian Studies, 15(1), 1-15.

Franks, C. E. (2016). The parliament of Canada. University of Toronto Press.

Friedman, A., \& Friedberg, C. (2021). Personalized politics and weakened parties—an axiom? Evidence from the Israeli case. Party Politics, 27(2), 258-268. https://doi.org/10.1177/1354068819855701

Ganghof, S., Eppner, S., Stecker, C., Heeß, K., \& Schukraft, S. (2019). Do minority cabinets govern more flexibly and inclusively? Evidence from Germany. German Politics, 28(4), 541-561. https://doi.org/10.1080/09644008.2019.1635120

Garand, J. C., \& Burke, K. M. (2006). Legislative activity and the 1994 republican takeover: Exploring changing patterns of sponsorship and cosponsorship in the US House. American Politics Research, 34(2), 159-188.

Godbout, J. F., \& Høyland, B. (2011). Coalition voting and minority governments in Canada. Commonwealth \& Comparative Politics, 49(4), 457-485. https://doi.org/10.1080/14662043.2011.615168

Godbout, J. F., \& Smaz, M. (2016). Party development in the early decades of the Australian parliament: a new perspective. Australian Journal of Political Science, 51(3), 478-495. https://doi.org/10.1080/10361146.2016.1182618

Green, M. N. (2015). Underdog politics: The minority party in the US House of Representatives. Yale University Press.

Green-Pedersen, C. (2010). Bringing parties into parliament: The development of parliamentary activities in Western Europe. Party Politics, 16(3), 347-369. https://doi.org/10.1177/1354068809341057

Halligan, J., \& Reid, R. (2016). Conflict and consensus in committees of the Australian parliament. Parliamentary Affairs, 69(2), 230-248. https://doi.org/10.1093/pa/gsv044

Heitshusen, V., Young, G., \& Wood, D. M. (2005). Electoral context and MP constituency focus in Australia, Canada, Ireland, New Zealand, and the United Kingdom. American Journal of Political Science, 49(1), 32-45. https://doi.org/10.1111/j.0092-5853.2005.00108.x

Hohendorf, L., Saalfeld, T., \& Sieberer, U. (2021). Veto power fosters cooperative behaviour: institutional incentives and government-opposition voting in the German Bundestag. West European Politics, 44(4), 921-945. https://doi.org/10.1080/01402382.2020.1739868

Höhmann, D., \& Sieberer, U. (2020). Parliamentary questions as a control mechanism in coalition governments. West European Politics, 43(1), 225-249. https://doi.org/10.1080/01402382.2019.1611986

Hughes, T. (2018). Assessing minority party influence on partisan issue attention in the US House of representatives, 1989-2012. Party Politics, 24(2), 197-208. https://doi.org/10.1177/1354068816654323

Jenkins, J. A., \& Monroe, N. W. (2016). On Measuring Legislative Agenda-Setting Power. American Journal of Political Science, 60(1), 158-174. https://doi.org/10.1111/ajps.12191

Jenny, M., \& Müller, W. C. (2012). Measuring the "Europeanization" of Austrian Law-Making: Legal and Contextual 
Factors. In The Europeanization of Domestic Legislatures (pp. 39-58). Springer, New York, NY.

Jensen, C. B., Proksch, S. O., \& Slapin, J. B. (2013). Parliamentary Questions, Oversight, and National Opposition Status in the European Parliament. Legislative Studies Quarterly, 38(2), $259-282$. https://doi.org/10.1111/lsq.12013

Kellermann, M. (2012). Estimating ideal points in the British House of Commons using early day motions. American Journal of Political Science, 56(3), 757-771.

Kellermann, M. (2013). Sponsoring early day motions in the British House of Commons as a response to electoral vulnerability. Political Science Research and Methods, 1(2), 263-280. DOI: https://doi.org/10.1017/psrm.2013.19

Kellermann, M. (2016). Electoral vulnerability, constituency focus, and parliamentary questions in the House of Commons. The British Journal of Politics and International Relations, 18(1), 90-106. https://doi.org/10.1111/1467-856X.12075

Kirkland, J. H., \& Kroeger, M. A. (2018). Companion bills and cross-chamber collaboration in the us congress. American Politics Research, 46(4), 629-670. https://doi.org/10.1177/1532673X17727094

Koger, G. (2003). Position Taking and Co-sponsorship in the US House. Legislative Studies Quarterly, 28(2), $225-246$. https://doi.org/10.3162/036298003X200872

Kolpinskaya, E. (2016). Does religion count for religious parliamentary representation? Evidence from Early Day Motions. The Journal of Legislative Studies, 22(1), 129-152. https://doi.org/10.1080/13572334.2015.1134905

Kolpinskaya, E. (2017). Substantive religious representation in the UK parliament: examining parliamentary questions for written answers, 1997-2012. Parliamentary Affairs, 70(1), 111-131. https://doi.org/10.1093/pa/gsw001

Krehbiel, K. (1992). Information and legislative organization. University of Michigan Press.

Meijers, M. J., \& Van der Veer, H. (2019). MEP Responses to Democratic Backsliding in Hungary and Poland. An Analysis of Agenda-Setting and Voting Behaviour. JCMS: Journal of Common Market Studies, 57(4), 838-856. https://doi.org/10.1111/jcms. 12850

Miquel, G. P. I., \& Snyder Jr, J. M. (2006). Legislative effectiveness and legislative careers. Legislative Studies Quarterly, 31(3), 347-381. https://doi.org/10.3162/036298006X201841

Mügge, L. M., van der Pas, D. J., \& van de Wardt, M. (2019). Representing their own? Ethnic minority women in the Dutch Parliament. West European Politics, 42(4), 705-727. https://doi.org/10.1080/01402382.2019.1573036

Norton, P. (2013). Parliament in British politics. Palgrave Macmillan.

Otjes, S., \& Louwerse, T. (2018). Parliamentary questions as strategic party tools. West European Politics, 41(2), 496-516. https://doi.org/10.1080/01402382.2017.1358936

Pearson, K., \& Dancey, L. (2011). Elevating women's voices in congress: Speech participation in the house of representatives. Political Research Quarterly, 64(4), 910-923. https://doi.org/10.1177/1065912910388190

Pedrazzani, A., Pellegata, A., \& Pinto, L. (2018). Economic crisis and lawmaking. The impact of crisis on legislative agenda in Italy. The Journal of Legislative Studies, 24(3), 315-337. https://doi.org/10.1080/13572334.2018.1516605

Proksch, S. O., \& Slapin, J. B. (2015). The politics of parliamentary debate. Cambridge University Press.

Rasch, B. E. (2011). Behavioural consequences of restrictions on plenary access: Parliamentary questions in the Norwegian Storting. The Journal of Legislative Studies, 17(3), 382-393. https://doi.org/10.1080/13572334.2011.595131

Rosenthal, M. (2018). Agenda Control by Committee Chairs in Fragmented Multi-party Parliaments: A Knesset Case Study. Israel Studies Review, 33(1), 61-80.

Russell, M., Gover, D., \& Wollter, K. (2016). Does the Executive dominate the Westminster legislative process? Six reasons for doubt. Parliamentary Affairs, 69(2), 286-308.

Saalfeld, T. (2011). Parliamentary questions as instruments of substantive representation: Visible minorities in the UK House of Commons, 2005-10. The Journal of Legislative Studies, 17(3), 271-289. https://doi.org/10.1080/13572334.2011.595121

Saalfeld, T., \& Bischof, D. (2013). Minority-ethnic MPs and the substantive representation of minority interests in the House of Commons, 2005-2011. Parliamentary Affairs, 66(2), 305-328. https://doi.org/10.1093/pa/gss084

Shugart, M. S., \& Taagepera, R. (2017). Votes from seats: Logical models of electoral systems. Cambridge University 
Press.

Sorace, M. (2018). Legislative Participation in the EU: An analysis of questions, speeches, motions and declarations in the 7th European Parliament. European Union Politics, 19(2), 299-320. https://doi.org/10.1177/1465116518757701

Soroka, S., Penner, E., \& Blidook, K. (2009). Constituency influence in parliament. Canadian Journal of Political Science/Revue canadienne de science politique, 42(3), 563-591.

Sotiropoulos, E. (2009). The Use and Misuse of Members' Statements. Canadian Parliamentary Review, 32(3), 10-14.

Strøm, K. (1997). Rules, reasons and routines: Legislative roles in parliamentary democracies. The Journal of Legislative Studies, 3(1), 155-174. https://doi.org/10.1080/13572339708420504

Sulkin, T., Testa, P., \& Usry, K. (2015). What gets rewarded? Legislative activity and constituency approval. Political Research Quarterly, 68(4), 690-702. https://doi.org/10.1177/1065912915608699

Terjesen, S., \& Trombetta, L. (2017). Gender diversity on boards in the United States, Australia, and Israel. In Gender Diversity in the Boardroom (pp. 235-259). Palgrave Macmillan, Cham.

Tuttnauer, O. (2020). Government-opposition relations in a fragmented, personalized, and multidimensional setting: The case of Israel. Party Politics, 26(2), 203-214. https://doi.org/10.1177/1354068818761198

Van Santen, R., Helfer, L., \& Van Aelst, P. (2015). When politics becomes news: An analysis of parliamentary questions and press coverage in three West European countries. Acta Politica, 50(1), 45-63.

Vliegenthart, R., \& Walgrave, S. (2011). Content matters: The dynamics of parliamentary questioning in Belgium and Denmark. Comparative Political Studies, 44(8), 1031-1059.

Wawro, G. (2000) Legislative Entrepreneurship in the U.S. House of Representatives. Ann Arbor: University of Michigan Press.

Wegmann, S. (2020). Policy-making power of opposition players: a comparative institutional perspective. The Journal of Legislative Studies, 1-25. https://doi.org/10.1080/13572334.2020.1843233

Zittel, T., Nyhuis, D., \& Baumann, M. (2019). Geographic representation in party-dominated legislatures: A quantitative text analysis of parliamentary questions in the German Bundestag. Legislative Studies Quarterly, 44(4), 681-711. https://doi.org/10.1111/1sq.12238

Appendix 1 . The dummy variables for each country and each term

\begin{tabular}{|l|c|}
\hline Dummy variable name & The relevant years \\
\hline Australia1 & $2007-2010$ \\
\hline Australia2 & $2010-2013$ \\
\hline Australia3 & $2013-2013$ \\
\hline Canada1 & $2008-2006$ \\
\hline Canada2 & $2011-2008$ \\
\hline Canada3 & $2015-2011$ \\
\hline Israel1 & $2006-2009$ \\
\hline Israel2 & $2009-2013$ \\
\hline Israel3 & $2013-2015$ \\
\hline US1 & $2009-2011$ \\
\hline US2 & $2011-2013$ \\
\hline US3 & $2013-2015$ \\
\hline UK1 & $2005-2010$ \\
\hline UK2 & $2015-2010$ \\
\hline UK3 & $2017-2015$ \\
\hline
\end{tabular}

\section{Copyrights}

Copyright for this article is retained by the author(s), with first publication rights granted to the journal.

This is an open-access article distributed under the terms and conditions of the Creative Commons Attribution license (http://creativecommons.org/licenses/by/4.0/). 